\title{
Response of Hot Pepper (Capsicum annuum L.) as Affected by NP Fertilizer and Planting Method on Yield and Yield Related Traits in West Hararghe Zone, Eastern Ethiopia
}

\author{
Gezahegn Assefa*, Sintayehu Girma, Dereje Deresa \\ Oromia Agricultural Research Institute, Mechara Agricultural Research Center, Horticulture and Spice Research Team, Mechara, Ethiopia
}

Email address:

gezeassefa@gmail.com (G. Assefa)

${ }^{*}$ Corresponding author

To cite this article:

Gezahegn Assefa, Sintayehu Girma, Dereje Deresa. Response of Hot Pepper (Capsicum annuum L.) as Affected by NP Fertilizer and Planting Method on Yield and Yield Related Traits in West Hararghe Zone, Eastern Ethiopia. American Journal of BioScience.

Vol. 8, No. 4, 2020, pp. 113-122. doi: 10.11648/j.ajbio.20200804.13

Received: May 11, 2020; Accepted: June 3, 2020; Published: July 28, 2020

\begin{abstract}
Hot Pepper is an important food and cash crop in eastern Ethiopia including Daro labu and Boke Districts of West Hararghe Zone. A field experiment was conducted in Daro labu and Boke Districts, under rainfed during 2016-2017 cropping season, with the objectives of to determine the influence of NP fertilizers rates and method of planting on the yield and yield components of hot pepper and to estimate the cost-benefit of application fertilize rates and planting method in hot pepper production. Mareko fana variety, which is the dominant hot pepper variety produced in the area was used as planting material for the study, The treatments consisted of five combined rates of Nitrogen and phosphorus $(0 / 0,41 / 46,61 / 69,82 / 92$ and $102 / 115 \mathrm{~kg}$ level of $\mathrm{N} / \mathrm{P}_{2} \mathrm{O}_{5} \mathrm{ha}^{-1}$ ) and three methods of planting (broadcasting, drilling and transplanting method) were used. The experiment was laid out as a randomized complete block design in a $5 \times 3$ factorial arrangement and replicated three times. From the combined analysis of variance over the location, the result revealed that the two main factors fertilizer rates and planting method had a significant effect on all traits, except that fertilizer and planting method had a non-significant effect on fruit diameter, from interaction effect of fertilizer rates and planting methods, the highest mean of plant height $(64.24 \mathrm{~cm})$, canopy diameter $(44.15 \mathrm{~cm})$ and fruit number $(26.70)$ per plant were obtained from 102/115kg N/P ha ${ }^{-1}$ in combined with drilling planting method. The highest fruit length $(9.33 \mathrm{~cm})$, diameter $(3.92)$, weight $(2.82 \mathrm{gm})$, marketable $(2.05 \mathrm{t} / \mathrm{ha})$ and total yield $(2.26 \mathrm{t} / \mathrm{ha})$ were recorded from plots that received $102 / 115 \mathrm{~kg} \mathrm{~N} / \mathrm{P} \mathrm{ha}^{-1}$ fertilizers combined with drilling planting method, while the lowest dry pod yield $\left(0.55 \mathrm{t} / \mathrm{ha}\right.$ ) was obtained from plot received control $0 / 0 \mathrm{~kg} \mathrm{NP} \mathrm{ha}{ }^{-1}$ combined with transplanting method. While the highest unmarketable fruit yield $(0.42 \mathrm{t} / \mathrm{ha})$ was recorded from control $(0 / 0)$ with the broadcasting method. Moreover, Partial budget analysis result has shown that application of 102/115 kg N/P ha ${ }^{-1}$ fertilizer rate with combined with drilling planting method was found to be economically viable with net income 71572.25 of Birr ha ${ }^{-1}$ with $265.28 \%$ marginal rate of return was obtained from the application of $102 / 115 \mathrm{~kg} \mathrm{~N}_{\mathrm{P}} \mathrm{ha}^{-1}$ fertilizer rate combined with drilling sowing method. Therefore, it could be recommended for the production of hot pepper crops in the study area and similar agro ecology.
\end{abstract}

Keywords: Fruit Diameter, Marginal Rate of Return, Marketable Yield and Total Fruit Yield

\section{Introduction}

Hot pepper (Capsicum annuum L.) belongs to the genus Capsicum and family Solanaceae [1]. The genus Capsicum consists of about 20 species and only four species are under cultivation, out of which $C$. pendulum and C. pubescens are restricted to South and Central America. The other two species such as $C$. annuum and $C$. frutescens are commonly cultivated throughout the world. Among the cultivated species the cultivation of Capsicum annuum is the most widely spread all over the world [2]. C. annuum is the most commonly cultivated species and all green chillies in the market and most of the dry chillies belong to this species Chilli, the fruit of Capsicum annuum L, is one of the most important commercial crops in the world. The origin of Capsicum species is extended from Mexico in the North to 
Bolivia in the South of Latin America, where it has been part of the human diet since about 7500BC [3].

Peppers are grown extensively under various environmental and climatic conditions. It is an important cash crop for smallholder farmers in developing countries such as Ethiopia, Nigeria, Ghana, China, India, Pakistan, Bhutan, Indonesia, Cambodia, and Thailand [4]. India is the largest producer of chilli in the world [5]. Owing to its high cash value and consumption rate the annual trade of chilli is approximately $17 \%$ of the total spice trade in the world [6].

Pepper is an important food and cash crop in Eastern and Central Africa, playing a major role in national food security and nutrition, poverty alleviation and income generation, and; provides employment opportunity in the production, processing and marketing sub-sectors. Hot pepper is in the daily diet of most Ethiopians. Peppers are widely grown in various parts of Ethiopia and the fruits are consumed as fresh, dried, or processed products, like vegetables, as spices or condiments. Today, the crop has not only attained economical but also traditional importance. The average daily consumption of hot pepper by Ethiopian adults is estimated $15 \mathrm{gm}$, which is higher than tomatoes and most other vegetables [7].

In terms of total production, the share of pepper is high as compared with other vegetables such as lettuce, tomatoes, head cabbage, onion, and others [8]. the national average yields of hot pepper are $6.3 \mathrm{tha}^{-1}$ for green pod and $1.8 \mathrm{t} \mathrm{ha}^{-1}$ for the dry pod, which is far below the dry pod yield (2.5-3.7 $\mathrm{t} \mathrm{ha}^{-1}$ ) of improved varieties harvested at research fields of Ethiopia and world average yield of 3 to $4 \mathrm{t} \mathrm{ha}^{-1}$ [9]. In Ethiopia several factors limiting crop yields have been identified by many researchers, the major ones are lack of stable well-adapted varieties, lack of knowledge in using optimum nutrient supply in every area of production zone, an insufficient supply of disease and insect pests' tolerant varieties. Most Ethiopian soils lack most of the macro and micronutrients that are required to sustain. This is exacerbated especially by Ethiopian fertilizer rates that are below international and regional standards Agriculture Growth Program [10]. Consequently, the yield and productivity of crops including hot pepper in Ethiopia are much lower than in other countries.

In Ethiopia, fertilizer use has increased notably since 1990 [11]. However, there is no related attainable yield increase, especially in hot pepper [12]. This may be due to the fact that small scale farmers do not have the required resources to make or purchase fertilizer and/or the farmers, do not apply the optimum amount of fertilizers rates to planting practices to harvest maximum yield from their land and due to the absence of recommendation that best fit to their specific area and production system [12].

Chemical fertilizer sources in Ethiopian agriculture have been limited to urea and Diammonium Phosphate (DAP) over the past five decades. Besides, concerning fertilizer and variety utilization in the study area, producers are overcome by lack of knowledge to use the right type and rate of inorganic fertilizers in combination with the right type of variety and best planting method, thus they are not getting a good yield. Application of the right amounts of fertilizers in pepper production has never been given attention by the growers in areas surrounding area. It is a usual practice to apply nitrogen and phosphorus fertilizers at the rates of 150 $\mathrm{kg} \mathrm{ha}^{-1}$ and $100 \mathrm{~kg} \mathrm{ha}^{-1}$ respectively.

In addition, application of $200 \mathrm{~kg} / \mathrm{ha}$ of DAP and 100 $\mathrm{kg} / \mathrm{ha}$ of urea was found optimum for better yield at Abobo [13]. Besides, the highest economic benefits of 74,096 birr/ha were obtained by using Mareko Fana variety and application of $50 \mathrm{~kg} \mathrm{~N} / \mathrm{ha}$ and $92 \mathrm{~kg} \mathrm{P}_{2} \mathrm{O}_{5} /$ ha [14]. The optimum doses of fertilizer increase the pepper growth, development and maximize the yield of pepper. Similarly, the highest fruit yield was obtained from blended fertilizer and $41 \mathrm{~kg} \mathrm{~N}+46$ $\mathrm{kg} \mathrm{P}_{2} \mathrm{O}_{5}+2.5 \mathrm{t} \mathrm{FYM} \mathrm{ha}^{-1}$ applications respectively [15].

In West Hararghe zone, hot pepper is a major spice and vegetable crop produced by the majority of farmers [16]. However, the yield of hot pepper is low due to the depletion of the soil nutrient in the area and failure of applying the optimum amount of fertilizers by farmers. In Daro labu and Boke districts, most of the crop nutrients such as nitrogen, phosphorus, and others are depleted [17]. Besides, In the study area, the Agronomy practice is different from farmer to farmers, with planting method and fertilizer rate. Direct sowing is more practice in a dry area to overcome the shortage of rainfall and minimize growth shock. However, this practice is low yielder and quality which is confirmed by many scholars in the world. Moreover, in drought areas in most time, the crop is unable to grow at maturity time.

Moreover, farmers in the study area are also conscious of the response of hot pepper to applied nutrients and raise the crop in homesteads using inorganic and organic fertilizers (Personal communication). However, they do not know the type and rate of inorganic fertilizers to be applied for individual crop species and cultivars for improving crop productivity. Moreover, regardless of the fertility status of the soil and types of cultivar, a blanket recommendation of 110 $\mathrm{kg} \mathrm{N} \mathrm{ha}^{-1}$ and $90 \mathrm{~kg} \mathrm{P}_{2} \mathrm{O}_{5} \mathrm{ha}^{-1}$ has been promoted in Ethiopia for a long time for the production of the crop [18] Besides, absence of area and specific recommendation of fertilizer rates are the causes of a large proportion of small-sized pod production that can be categorized as unmarketable dry pods and low yield.

In addition, no attempt has been made to determine the appropriate rate of blended fertilizer to produce a high proportion of marketable dry pods. In order to improve the production and productivity of pepper in the study area, and ultimately to improve the livelihood options of households, so it is necessary to conduct research in the area which can seek solutions to the above problems to identify optimum fertilizer rates and planting method, therefore, the present study was conducted as objectives to identify optimum fertilizer rate and the best way of planting method of hot pepper for successful growth and yield of hot pepper plants. In addition to estimate cost-benefit of the application of NP fertilizer at different rates with a combination of planting method for the production of Hot pepper in study areas. 


\section{Materials and Methods}

\subsection{Description of the Study Areas}

The study was conducted under rain-fed conditions during 2016-2017 main cropping season at Daro Labu district (Milkaye FTC) and Boke district (Cabi FTC), West Hararghe zone, Oromia Regional State. Daro labu and Boke districts are located in the eastern part of the country, 437 and $391 \mathrm{~km}$ from Addis Ababa, respectively. Geographically, Daro labu and Boke districts are located between $70^{\circ} 52^{\prime} 10^{\prime \prime}$ and $80^{\circ}$ $42^{\prime} 30^{\prime \prime} \mathrm{N}$ and $40^{\circ} 23^{\prime} 57^{\prime \prime}$ and $41^{\circ} 09^{\prime} 14^{\prime \prime} \mathrm{E}$, respectively (Figure 1).

Daro labu district is characterized mostly by flat and undulating land features with altitude ranging from 1350 up to $2450 \mathrm{~m}$. a. s. $l$. with an average annual rainfall of 963 $\mathrm{mm} /$ year [19]. During the 2016-2017 cropping season with the maximum and minimum rainfall is $1200 \mathrm{~mm}$ and $900 \mathrm{~mm}$ recorded at Boke district. Daro labu district has the mean annual minimum and maximum temperature of 14 and $26^{\circ} \mathrm{C}$ were recorded and an average of $16^{\circ} \mathrm{C}$ while meaning annual minimum and maximum temperature $13.56^{\circ} \mathrm{C}$ and $25^{\circ} \mathrm{C}$ at Boke district, respectively [20]. In two districts of study areas, the rainfall is erratic; onset is unpredictable, its distribution and amount are also quite irregular. Consequently most "kebele" frequently face a shortage of rain; hence moisture stress is one of the major production constraints in the district [19]. The pattern of rainfall is bimodal and its distribution is mostly uneven in two districts. Generally, there are two rainy seasons: the short rainy season "Belg" lasts from mid-February to April whereas the long rainy season "kremt" is from June to September.

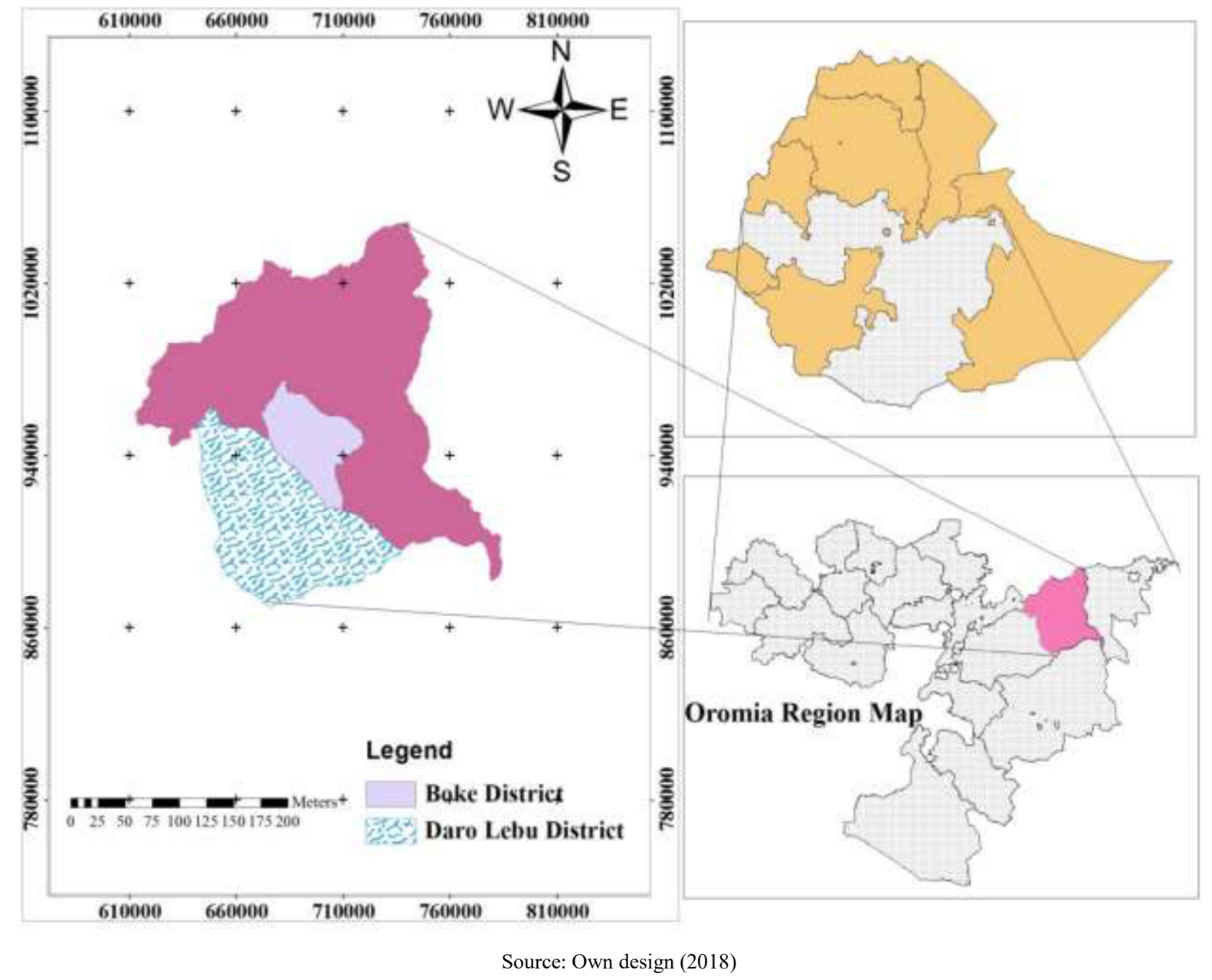

Figure 1. Map of study areas.

\subsection{Experimental Materials, Treatments, and Design}

Hot pepper (Capsicum annuum L.) variety known as "Mareko Fana" which was adaptable to the study area. It is characterized by dark red pungent, long pod size and the most widely cultivated variety that grows over a wide range of agro-ecologies in Ethiopia [21] was used for this study. The treatments consisted of five combined rates of N/P fertilizer (0/0, 41/46, 61/69, 82/92 and 102/115 $\left.\mathrm{kg} \mathrm{ha}^{-1}\right)$ and three methods of planting (broadcasting, drilling and transplanting). The experiment was laid out as a Randomized Complete Block Design (RCBD) in $5 \times 3$ factorial arrangements with three replications. There were 15 treatment combinations, which were assigned to each plot randomly. The total number of plots was 45 and each plot had a gross area of $7.2 \mathrm{~m}^{2}$ with $3 \mathrm{~m}$ length and $2.4 \mathrm{~m}$ width. 
Each plot contained four rows of hot pepper plants, with each row accommodating 10 plants with a total population of 40 plants per plot at the spacing of $60 \mathrm{~cm}$ and $30 \mathrm{~cm}$ between rows and plants, respectively. The spacing between plots and adjacent blocks was $1 \mathrm{~m}$ and $1.5 \mathrm{~m}$, respectively. Plants in the two outer rows, as well as those at both ends of each row, were not considered for data collection to avoid edge effects. Cultural practices (weeding, cultivation, etc) were done as per the recommendation made for the plots.

\subsection{Treatments Application}

The fertilizers used as sources of $\mathrm{N}$ and $\mathrm{P}_{2} \mathrm{O}_{5}$ were urea $(46 \% \mathrm{~N})$ and Diammonium sulphate $(18 \% \mathrm{~N}, 46 \% \mathrm{P}, 0 \% \mathrm{~K})$, respectively. Nitrogen fertilizer was applied in two splits with the form of urea, the first half dose was done of $\mathrm{N}$ along with a full dose of Phosphorus at sowing (for broadcasting and drilling) or transplanting method. While the remaining dose of the $\mathrm{N}$ was applied during an active stage of vegetative growth (4 weeks after sowing/transplanting)

\subsection{Data Collection}

During two years of the study period, five hot pepper plant stands were randomly selected from the middle rows of each treatment plot and tagged for sampling at various stages. The selected plants per treatments were sampled in every 15 days for a number of fruits per plant but, data on plant height $(\mathrm{cm})$, and a number of main branches per plant was taken at the final harvest. Besides, mature fruits sample were harvested for each treatment at 15 days interval from November to December 2016-2017. The matured fruits picked from each plot was sun-dried and the dry matter (dry weight) were weighed by analytical balance scale.

\subsection{Partial Budget Analysis}

The economic analysis was carried out by using the methodology described in which prevailing market prices for inputs at planting and outputs at harvesting were used. All costs and benefits were calculated on a basis in Birr [22]. The concepts used in the partial budget analysis were the mean marketable dry pods yield of each treatment, the gross benefit (GB) $\mathrm{ha}^{-1}$ (the mean marketable dry pods yield for each treatment) and the field price of fertilizers (the costs of Dap and Urea and the application of labour costs).

Gross average marketable dry pod yield (tons ha ${ }^{-1}$ ) (AvY): AvY was an average yield of each treatment.

Adjustable marketable dry pod yield $=$ (marketable dry pod yield $\mathrm{x} 0.1$ ). is the average marketable dry pods yield adjusted downward by $10 \%$ to reflect the difference between the experimental yield and yield of farmers [22].

$\mathrm{AjY}=\mathrm{AvY}-(\mathrm{AvY}-0.1)$

Gross field benefit (GFB): GFB was computed by multiplying field/farm gate price that farmers receive for the Hot pepper when they sell it by adjusted marketable dry pods yield.

$\mathrm{GFB}=\mathrm{AjY} \times \mathrm{x}$ field/farm gate price for the crop

Total variable cost (TVC): Total cost was the cost of fertilizers and application cost of fertilizers as differ dosage for the experiment and pod yield transportation. The costs of other inputs and production practices such as land preparation, planting, earthing up, weeding, top killing, and harvesting was considered the same or are insignificant among treatment.

Net Income (NI) or Net Benefit (NB): - was calculated as the amount of money left when the total variable costs for inputs (TVC) are deducted from the gross field benefit (GFB). NB = GFB - TVC.

The marginal rate of return (MRR\%): was calculated by dividing the change in a net benefit $(\triangle N B)$ by the change in total variable cost (TVC).

$$
\operatorname{MRR}(\%)=\frac{(\text { Change of Net Benefit }(\Delta \mathrm{NB})}{\text { Change of Total Variable Cost }((\Delta T C)} \times 100
$$

Where: $\Delta \mathrm{NI}=$ change in Net benefit; $\Delta \mathrm{TVC}=$ change in Total Variable Cost

\subsection{Data Analysis}

The collected data were analyzed by R-software. All significant treatment mean differences were separated using the Least Significant Difference (LSD) test at 5\% probability level.

\section{Results and Discussion}

\subsection{Physico-chemical Properties of the Experimental Soil}

The results of the pre-sowing composite soil sample laboratory analyses indicated that the soil textural class of experimental site was $16 \%$ silt, $48 \%$ clay and $36 \%$ sand (Table 1). Thus, the texture of the soil was clay according to textural classification system [23]. The texture indicates the degree of weathering, nutrient, and water holding capacity of the soil. Furthermore, the clay soil texture was suitable for hot pepper and other major crops production due to its good ability to retain nutrients and available water. However, clay soil has a high proportion of clay particles. It is the cause's two biggest drawbacks of soils as it swells when wet and creating difficulty to till (heavy of soils) and cracks when dry exposing the roots to the atmospheric elements [24].

The $\mathrm{pH}$ of the soil was almost slightly acidic (6.60)[25]. This value falls in the $\mathrm{pH}$ range that was very conducive for hot pepper production as normal optimum soil $\mathrm{pH}$ for production is from 5.2 - 6.5 [26]. The Cation Exchange Capacity (CEC) of the soil was $(27.40 \mathrm{meq} / 100 \mathrm{~g})$ which was very high [27]. Therefore, there could be no limitation to the growth of the hot pepper crop in terms of this soil CEC. The total soil nitrogen content of experimental soil was $0.15 \%$ which is moderate [27]. The available phosphorus content of the soil was medium (15.66 ppm)[28]. Hot pepper needs a good supply of readily available phosphorus since the root system is not extensive and does not readily utilize less available $\mathrm{P}$ forms. Thus, according to the soil laboratory results, the soil of the study area was suitable for the 
production of hot pepper and other crops.

Table 1. Physical and chemical properties of the experimental site before-planting at Boke and Daro labu districts, during in, 2016-2017.

\begin{tabular}{llll}
\hline 1. Properties (\%) & Result & Rating & References \\
\hline Sand (\%) & 36 & & - \\
Silt (\%) & 16 & & - \\
Clay (\%) & 48 & & (USDA, 1987) \\
Textural Class & Clay & & Tekalign (1991) \\
2. Chemical properties & & & Slightly acidic \\
$\mathrm{pH}\left(1: 2.5 \mathrm{H}_{2} \mathrm{O}\right)$ & 6.60 & Medium & Tekalign (1991) \\
Electrical conductivity & 3.00 & Medium & Newey (1906) \\
Organic Matter /OM/ (\%) & 1.74 & Very low & Murphy (2007) \\
Organic Carbon /OC/ (\%) & 9.16 & Very high & Murphy (1968) \\
Carbon-Nitrogen ratio (C: N) & 43.82 & Medium & Cottenie (1980) \\
CEC (meq/100 g soil) & 0.15 & Medium & EthioSIS (2014) \\
Total Nitrogen /TN/ (\%) & 10.79 & Medium & \\
Available Phosphorus /P/(ppm) & 15.66 & & \\
\hline
\end{tabular}

\subsection{Growth Traits}

\section{Plant Height and Canopy Diameter}

Plant height and canopy diameter were significantly $(\mathrm{P}<0.05)$ influenced by fertilizer rates and planting methods. The tallest plant $(58.77$ and $69.73 \mathrm{~cm})$ were recorded from the application of 102/115 kg N/P $\mathrm{P}_{2} \mathrm{O}_{5} \mathrm{ha}^{-1}$ combined with drilling method at Boke and Daro labu districts, respectively, whereas the shortest $(44.42 \mathrm{~cm}$ and $40.07 \mathrm{~cm})$ plant were observed from unfertilized plot combined with the broadcasting method at Boke and Daro labu, respectively. Similarly, widest canopy diameter $(44.62 \mathrm{~cm}$ and $49.10 \mathrm{~cm})$ plants were measured from the application of $102 / 115 \mathrm{~kg}$ $\mathrm{N} / \mathrm{P}_{2} \mathrm{O}_{5}$ ha ${ }^{-1}$ combined with drilling sowing and the transplanting method at Boke and Daro labu district, respectively. While, the smallest canopy diameter $(36.42 \mathrm{~cm}$ and $24.03 \mathrm{~cm}$ ) plant were recorded from control $0 / 0$ combined with the broadcasting method at Boke and Daro labu districts, respectively (Table 2).

From combined analysis variance over location showed that tallest plant height $(64.25 \mathrm{~cm})$ and wider canopy diameter $(44.15 \mathrm{~cm})$ were recorded from 102/115 kg ha $\mathrm{N}^{-1} \mathrm{P}_{2} \mathrm{O}_{5} \mathrm{ha}^{-1}$ with combined drilling sowing, while shortest plant height $(42.24 \mathrm{~cm})$ and smallest canopy diameter $(30.05 \mathrm{~cm})$ were recorded from control $(0 / 0) \mathrm{N} / \mathrm{P}_{2} \mathrm{O}_{5}$ with the broadcasting method (Table 4). This could be due to better nutrient supply might, in turn, better plant height and canopy diameter, further noted that inorganic fertilizers supplied most of the essential nutrients at growth stage and it could be due to the occurrence this condition. The significant tallest plant and highest canopy diameter were observed towards the application of higher rates of $\mathrm{N} / \mathrm{P}$ fertilizer that might be ascribed to the increased availability of nitrogen and phosphorus fertilizer in the soil for uptake by plant roots, which might have sufficiently enhanced vegetative growth through increasing cell division and elongation. Similarly, Moreover, increasing the application of nitrogen significantly increased plant height [29]. In addition to this, the current investigation is also consistent with the findings of reported that the tallest plant height was recorded on $15 \mathrm{~kg} \mathrm{NPS} \mathrm{ha}^{-1}$ [30]. Similarly, the tallest plant height was recorded at $41 \mathrm{~kg}$
$\mathrm{N} \mathrm{ha}^{-1}+46 \mathrm{~kg} \mathrm{P}_{2} \mathrm{O}_{5} \mathrm{ha}^{-1}$ [31]. Drilling method of sowing could be minimizing competition among plants to the resource. Besides, widest canopy diameter in plants was measured from the application high fertilizer rates with drilling method. This study conforms noted that nitrogen has a positive effect on branching of pepper plants [32]. Accordingly, the highest plant canopy $(33.25 \mathrm{~cm})$ was recorded from $140 \mathrm{~kg} \mathrm{~N} \mathrm{ha}^{-1}$ and $60 \mathrm{~kg} \mathrm{P}_{2} \mathrm{O}_{5} \mathrm{ha}^{-1}$ [33].

\subsection{Yield related Traits}

\subsubsection{Fruit Number Per Plant and Length}

Significant variation was observed among the different treatments due to different doses of combined NP and sowing method in respect of fruit number and average fruit length at Daro labu, whereas, non significance at Boke district. The mean comparison of treatments revealed that significantly maximum numbers of red fruits $(29.67 \mathrm{~cm})$ per plant were obtained from the plot treated with a supply of $102 / 115 \mathrm{~kg}$ $\mathrm{N} / \mathrm{P}_{2} \mathrm{O}_{5}$ ha $^{-1}$ in combined with drilling planting method at Daro labu district (Table 2). On the contrary, the minimum numbers of red fruits 14.67) per plant were counted from an unfertilized plot combined with drilling methods at Daro labu districts, respectively (Table 2).

Similarly, analysis of data from two sites over location showed that there was a statistically significant difference at $(p<0.05)$ among the treatment (Table 4). The highest fruit number $(22.70)$ per plant and fruit length $(9.33 \mathrm{~cm})$ were recorded from the application of $102 / 115 \mathrm{~kg} \mathrm{~N} / \mathrm{P}_{2} \mathrm{O}_{5} \mathrm{ha}^{-1}$ in combined with the drilling method, respectively (Table 4). It may be due to the effect of NP which increases the main branches, if there are more brunches there may be a greater number of fruits. As a general trend, it was observed that the number of fruits per plant was increased in plots that received the combinations of highest fertilizer rates in combined with the drilling method. In this study, the application of a higher rate of N/P might have enhanced fruit set. This finding is in agreement who studied the effect of farmyard manure and poultry manure on growth of pepper and found that poultry manure at a rate of $41 \mathrm{~kg} \mathrm{~N} \mathrm{ha}^{-1}+46 \mathrm{~kg} \mathrm{P}_{2} \mathrm{O}_{5} \mathrm{ha}^{-1}+5 \mathrm{tha}^{-1}$ FYM significantly increased fruits of pepper [16].

The results from this study show that NP application 
enhanced the growth performance of pepper in terms of increased fruit number per plant. The increasing number of fruits from NP and drilling method planting was due to better and earlier canopy formation which checked the growth and reduced competition for nutrients from the plant. Besides, [33] reported that application of $75 \mathrm{~kg} \mathrm{~N} \mathrm{ha}^{-1}$ which gave the best plant growth performance also produced the highest number of fruits and fruit yield. Flower formation increased as soil $\mathrm{N}$ concentration increased as a result of $\mathrm{N}$ fertilizer such that higher fruit set can be explained by the effect on initial stimulation of the flowering process which leads to greater fruit formation [34].

The maximum fruit length was recorded in a high number of fertilized plots with the combined broadcasting method, which may be ascribed mainly to inorganic fertilizer suboptimum for plant growth. Whereas, Plants in the unfertilized plot produced fruits significantly short in length and optimum amount of NP fertilizer might be important to obtain large size fruits. This might be due to nutrients supply until the optimum level. It conforms that increasing nitrogen to $100 \mathrm{~kg}$ $\mathrm{ha}^{-1}$ result in the highest increase in pod length by about $69 \%$ over the control [34].

The increase in fruit yield could be related to the significant increase in fruit length and number per pod. The fruit number and length could increase the dry matter of fruit that increases the fruit yield. The results indicated that the application of inorganic fertilizers and planting methods that produced fruits with the highest number and length and thereby high economic return for farmers. These results are similar to that of obtained that highest yield due to an improvement in fruit size in response to $140 \mathrm{~kg} \mathrm{~N} \mathrm{ha}^{-1}$ and 60 $\mathrm{kg} \mathrm{P}_{2} \mathrm{O}_{5} \mathrm{ha}^{-1}$. [33]

Table 2. Effect of combined application of NP fertilizers and planting method on growth and yield related traits of hot pepper at Boke and Daro labu districts in 2016-2017.

\begin{tabular}{|c|c|c|c|c|c|c|c|c|}
\hline \multirow{3}{*}{$\begin{array}{l}\text { Fertilizer rate N/P } \\
\left(\mathrm{kg} \mathrm{ha}^{-1}\right) \text { Planting } \\
\text { method }\end{array}$} & \multicolumn{2}{|c|}{ Plant height (cm) } & \multicolumn{2}{|c|}{ Canopy diameter (cm) } & \multicolumn{2}{|c|}{ Fruit number per plant } & \multicolumn{2}{|c|}{ Fruit length (cm) } \\
\hline & & & \multicolumn{4}{|c|}{ Location } & \multirow[b]{2}{*}{ Boke } & \multirow[b]{2}{*}{ Daro labu } \\
\hline & Boke & Daro labu & Boke & Daro labu & Boke & Daro labu & & \\
\hline $0 / 0+\mathrm{BC}$ & $44.42^{\mathrm{d}}$ & $40.07^{\mathrm{f}}$ & $36.42^{b}$ & $24.03^{\mathrm{f}}$ & 10.04 & $15^{\mathrm{b}}$ & 9.85 & $7.84^{\mathrm{d}}$ \\
\hline $0 / 0+\mathrm{DR}$ & $52.3^{\mathrm{abc}}$ & $45.47^{\mathrm{ef}}$ & $36.02^{\mathrm{b}}$ & $29.03^{\mathrm{ef}}$ & 11.83 & $14.67^{b}$ & 8.54 & $9.35^{\mathrm{abc}}$ \\
\hline $0 / 0+\mathrm{TR}$ & $47.8^{\mathrm{cd}}$ & $51.27^{\mathrm{c}-\mathrm{f}}$ & $37.38^{\mathrm{b}}$ & $43.43^{\mathrm{abc}}$ & 12.24 & $26.47^{\mathrm{ab}}$ & 8.26 & $8.54^{\mathrm{cd}}$ \\
\hline $41 / 46+B C$ & $52.87^{\mathrm{abc}}$ & $60.60^{\mathrm{a}-\mathrm{d}}$ & $39.78^{\mathrm{ab}}$ & $33.43^{\mathrm{de}}$ & 12.15 & $19.00^{\mathrm{a}}$ & 9.52 & $8.79^{\text {bcd }}$ \\
\hline $41 / 46+D R$ & $54.23^{\mathrm{ab}}$ & $63.07^{\mathrm{a}-\mathrm{d}}$ & $39.57^{\mathrm{ab}}$ & $37.97^{\text {cd }}$ & 13.75 & $24.33^{\mathrm{ab}}$ & 10.08 & $8.97^{\mathrm{a}-\mathrm{d}}$ \\
\hline $41 / 46+\mathrm{TR}$ & $48.03^{\text {cd }}$ & $50.80^{\text {def }}$ & $38.8^{\mathrm{ab}}$ & $46.77^{\mathrm{ab}}$ & 12.53 & $29.57^{\mathrm{a}}$ & 8.89 & $9.12^{\mathrm{abc}}$ \\
\hline $61 / 69+\mathrm{BC}$ & $54.17^{\mathrm{abc}}$ & $63.60^{\mathrm{a}-\mathrm{d}}$ & $37.97^{\mathrm{ab}}$ & $33.97^{\mathrm{de}}$ & 12.17 & $20.00 \mathrm{a}^{\mathrm{b}}$ & 10.11 & $8.75^{\text {bcd }}$ \\
\hline $61 / 69+\mathrm{DR}$ & $55.07^{\mathrm{ab}}$ & $64.33^{\mathrm{abc}}$ & $42.62^{\mathrm{ab}}$ & $37.93^{\mathrm{cd}}$ & 13.93 & $28.10^{\mathrm{a}}$ & 9.38 & $8.36^{\mathrm{cd}}$ \\
\hline $61 / 69+\mathrm{TR}$ & $47.8^{\text {cd }}$ & $51.27^{\mathrm{c-f}}$ & $35.83^{\mathrm{b}}$ & $44.11^{\mathrm{abc}}$ & 13.94 & $27.93^{\mathrm{a}}$ & 9.05 & $9.26^{\mathrm{abc}}$ \\
\hline $82 / 92+\mathrm{BC}$ & $55.23^{\mathrm{ab}}$ & $62.07^{\mathrm{a}-\mathrm{d}}$ & $37.82^{\mathrm{ab}}$ & $37.10^{\text {cde }}$ & 12.08 & $20.33^{\mathrm{ab}}$ & 9.09 & $9.79^{\mathrm{ab}}$ \\
\hline $82 / 92+D R$ & $56.23^{\mathrm{a}}$ & $65.73^{\mathrm{ab}}$ & $41.17^{\mathrm{ab}}$ & $38.47^{\mathrm{bcd}}$ & 14.52 & $20.17^{\mathrm{ab}}$ & 10.89 & $8.40^{\mathrm{cd}}$ \\
\hline $82 / 92+\mathrm{TR}$ & $48.37^{\text {cd }}$ & $53.67^{\mathrm{b}-\mathrm{e}}$ & $40.00^{\mathrm{ab}}$ & $46.87^{\mathrm{ab}}$ & 10.43 & $26.47^{\mathrm{ab}}$ & 9.79 & $8.37^{\mathrm{cd}}$ \\
\hline $102 / 115+\mathrm{BC}$ & $57.63^{\mathrm{a}}$ & $68.40^{\mathrm{a}}$ & $40.57^{\mathrm{ab}}$ & $41.53^{\mathrm{a}-\mathrm{d}}$ & 13.42 & $24.00^{\mathrm{ab}}$ & 9.81 & $7.93^{\mathrm{d}}$ \\
\hline $102 / 115+\mathrm{DR}$ & $58.77^{\mathrm{a}}$ & $69.73^{\mathrm{a}}$ & $44.62^{\mathrm{a}}$ & $43.67^{\mathrm{abc}}$ & 15.72 & $29.67^{\mathrm{a}}$ & 8.56 & $10.10^{\mathrm{a}}$ \\
\hline $102 / 115+\mathrm{TR}$ & $49.17^{\mathrm{bcd}}$ & $52.93^{\mathrm{b-f}}$ & $37.47^{\mathrm{b}}$ & $49.10^{\mathrm{a}}$ & 12.71 & $27.93^{\mathrm{a}}$ & 8.98 & $8.51^{\mathrm{cd}}$ \\
\hline Mean & 52.14 & 57.56 & 39.06 & 39.16 & 12.77 & 23.53 & 9.38 & 8.81 \\
\hline CV (\%) & 11.02 & 14.02 & 15.07 & 13.31 & 39.00 & 30.54 & 32.82 & 7.88 \\
\hline LSD $5 \%$ & 6.64 & 13.48 & 6.80 & 8.70 & 5.76 & 12.00 & 3.56 & 1.15 \\
\hline F-test & $*$ & $*$ & $*$ & $*$ & $\mathrm{Ns}$ & $*$ & $\mathrm{Ns}$ & $*$ \\
\hline
\end{tabular}

Means within column followed by the same letter (s) are not significantly different at $5 \%$ level of significance, LSD $(5 \%)=$ Least significant difference at $\mathrm{p}=$ 0.05 and $\mathrm{CV}(\%)=$ Coefficient of variation in percent, $\mathrm{BC}=\mathrm{Broad}$ casting, $\mathrm{TR}=$ Transplanting, $\mathrm{DR}=$ Drilling

\subsubsection{Fruit Diameter and Weight}

The analysis of variance also revealed that a combined application of NP fertilizer with different sowing method has affected significantly $(\mathrm{P}<0.01)$ the fruit diameter and weight at Daro labu district, while, on fruit weight non significantly $(\mathrm{P}<0.01)$ at Boke district (Table 3). The highest fruit diameter $(5.26$ and $2.58 \mathrm{~cm})$ were recorded from $102 / 115 \mathrm{~kg} \mathrm{~N} / \mathrm{P}_{2} \mathrm{O}_{5}$ with the drilling and $102 / 115 \mathrm{~kg} \mathrm{~N} / \mathrm{P}_{2} \mathrm{O}_{5}$ with the broadcasting at Boke and Daro labu districts, respectively, while the smallest fruit diameter $(4.68$ and $1.96 \mathrm{~cm})$ was recorded from control $(0 / 0)$ in combined with drilling and transplanting method at Bako and Daro labu, respectively (Table 3).

Similarly, from combined analysis result of the two locations shown that the highest fruit weight $(2.82 \mathrm{gm})$ was recorded from 102/115 kg N/$/ \mathrm{P}_{2} \mathrm{O}_{5}$ combined with drilling method (Table 4), at the same time, the lowest fruit weight $(2.10 \mathrm{gm})$ was observed in control treatment in combined with transplanting method (Table 4). On the other hand, the minimum weight of fruit was obtained from the unfertilized plot that received lower rates of inorganic. Average fruit weight per plant increased gradually with the increase of NP dose with the combined method of planting. The increase pod number may increase due to increase flowering. It is also in conformity that fruit weight increased linearly with seed number in sweet pepper [35].

The increased in pod width with increased nitrogen application could be attributed to enhanced assimilates partitioning by plants grown on plots with adequate nitrogen levels. Larger and wider hot pepper pods are considered to be the best in quality and have better demand for fresh as well as dry pod use in Ethiopian markets [36]. Application of organic and inorganic fertilizers increased pepper pod quality 
parameters including pod width [36]. Therefore, the pod size and length attained at $102 / 115 \mathrm{~kg} \mathrm{~N} / \mathrm{P}_{2} \mathrm{O}_{5} \mathrm{ha}^{-1}$ are within the range of preference by consumers in the market in the country, and are, hence, likely to be picked up by consumers over the thinner and shorter pods.

\subsubsection{Marketable Yield and Unmarketable Yield and Total Yield (t/ha)}

The analysis of variance showed that the main effect of blended NP fertilizer and method of planting and their interaction effect had a significant effect $(p<0.01)$ on marketable yield and unmarketable yield and total yield ( $\mathrm{t} / \mathrm{ha})$ (Table 4). The highest dry marketable yield (2.05 t/ha) was observed in 102/115 kg N/P $\mathrm{P}_{2} \mathrm{O}_{5}$ ha $^{-1}$ combined with drilling method at over locations. At the same time, the lowest dry marketable yield $(0.40 \mathrm{t} / \mathrm{ha})$ was recorded from control $(0 / 0)$ combined with the transplanting method (Table 4). The maximum marketable yield obtained might be attributed to the enhanced pod length, pod width, higher seed weight, seed number per pod and higher total dry pod weight per plant obtained at these levels of fertilizer rates. It conforms with that pod length, width and total dry pod weight per plant were positively correlated with marketable green pod yield in pepper [37, 34]. It is supported by highest marketable yield was obtained at $100 \mathrm{~kg} \mathrm{~N} \mathrm{ha}^{-1}$ which was $267 \%$ higher than the control [38].

This, in turn, had resulted in the development of pods that are relatively healthy, attractive, and acceptable in markets. Inaddition that maximum marketable dry fruit yield $\mathrm{t}$ ha- ${ }^{1}$ was obtained from plots fertilized $41 \mathrm{~kg} \mathrm{Nha}^{-1}+46 \mathrm{~kg} \mathrm{P}_{2} \mathrm{O}_{5} \mathrm{ha}^{-1}+$ $5 \mathrm{t} \mathrm{ha}^{-1}$ FYM [31]. Similarly, the highest marketable pod yield $\left(2.22 \mathrm{t} \mathrm{ha}^{-1}\right)$ was obtained from plots treated with a blended fertilizer rate of $150 \mathrm{~kg} \mathrm{NPSBZn}+44 \mathrm{~kg} \mathrm{~N} \mathrm{ha}^{-1}$ [39].

Unmarketable pod yield was significantly $(\mathrm{P}<0.01)$ affected by fertilizer rates and method of sowing seed at two locations (Boke and Daro labu) districts (Tables 3 and 4). The highest unmarketable yield $(0.082 \mathrm{t} / \mathrm{ha})$ was obtained from the control treatment $(0 / 0)$ with combined broadcasting (Table 4$)$. In line with this study by [30] who reported that the highest unmarketable pod dry yield $(0.19 \mathrm{t} / \mathrm{ha})$ was observed in treatment using $150 \mathrm{NPS} \mathrm{kg} / \mathrm{ha}$. The production of high unmarketable yield from lower rate combinations might also be because of the moisture availability and NP level to the crop might be lower in relative to other treatments.

Total dry fruit yield was significantly $(\mathrm{P} \leq 0.05)$ affected by NP fertilizer rates and planting method at two locations. The highest total yield (2.26 t/ha) was obtained from $102 / 115 \mathrm{~kg} \mathrm{~N} / \mathrm{P}_{2} \mathrm{O}_{5} \mathrm{ha}^{-1}$ combined with drilling method, while the lowest total yield (0.55 t/ha) was obtained from control treatment combined with transplanting (Table 4). Thus, the application of NP fertilizers direct sowing hot pepper seed improved dry fruit yield. This could be attributed to the higher mean fruit length, width, weight, seed number and a relatively larger number of marketable fruits obtained at this level of fertilizer supply.

The increase in dry matter yield of fruits with increasing level of nitrogen and phosphorus fertilizers conforms with the result of that dry matter yield of pepper fruits is directly correlated with the amount of nutrient supplied to the plant [40]. This result is in agreement with the observed of with the vegetative growth yield and quality of pepper significantly improved through nitrogen and phosphorus fertilization [40].

Table 3. Effect of combined application of NP fertilizers and planting method on yield and yield traits of hot pepper at Boke and Daro labu districts in 20162017 cropping season.

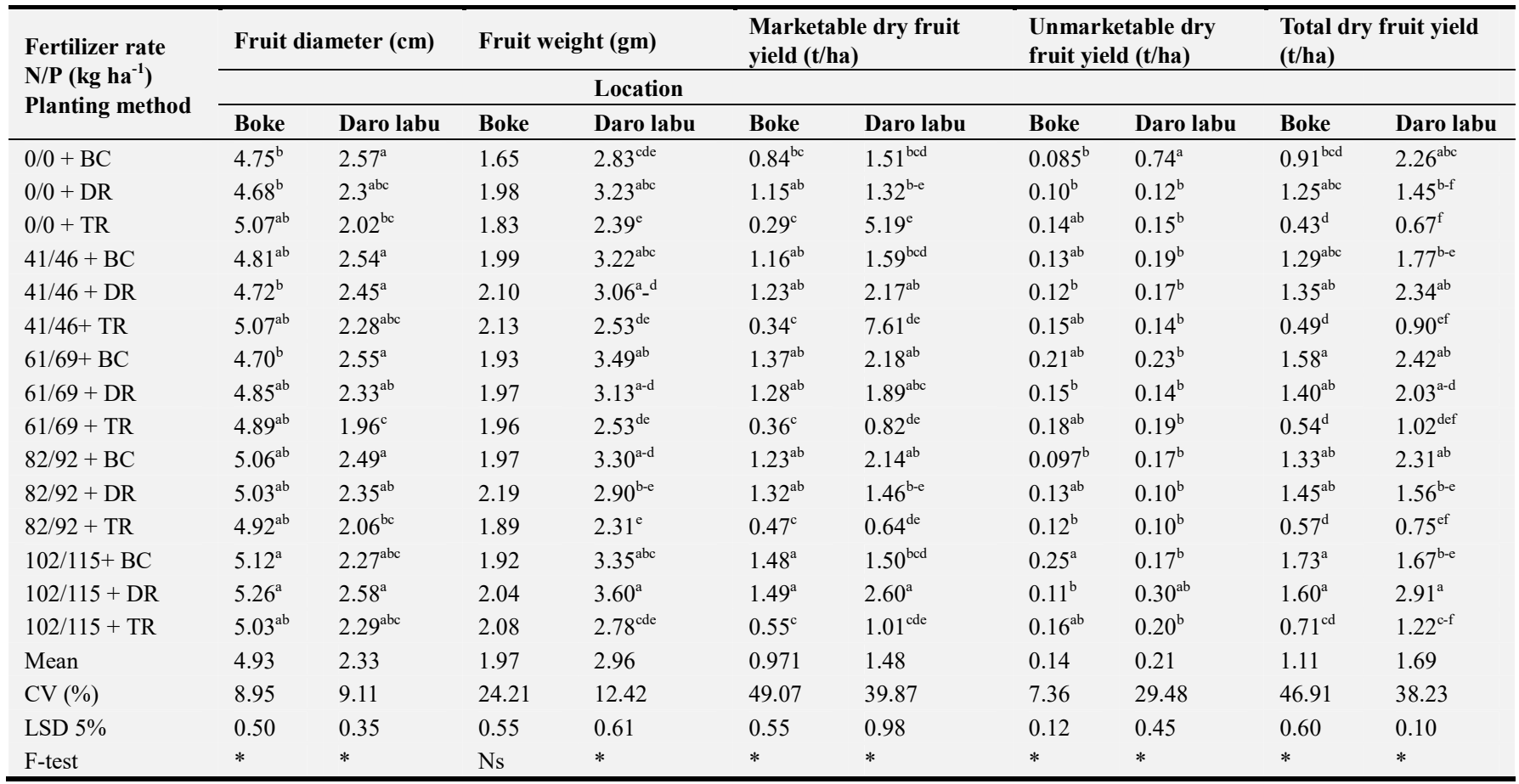

Means within column followed by the same letter (s) are not significantly different at $5 \%$ level of significance, LSD $(5 \%)=$ Least significant difference at $\mathrm{p}=$ 0.05 and $\mathrm{CV}(\%)=$ Coefficient of variation in percent, $\mathrm{BC}=$ Broad casting, $\mathrm{TR}=$ Transplanting, $\mathrm{DR}=\mathrm{Drilling}$ 
Table 4. Effect of combined application of NP fertilizers and planting method on yield traits of hot pepper at Boke and Daro labu districts, in 2016-2017 cropping season.

\begin{tabular}{|c|c|c|c|c|c|c|c|c|c|}
\hline $\begin{array}{l}\text { Fertilizer rate N/P (kgha }{ }^{-} \\
\text {1) Planting method }\end{array}$ & PH (cm) & CD (cm) & FNPP & FL (cm) & FD (cm) & $F(g)$ & M (t/ha) & UNMY (t/ha) & TYD (t/ha) \\
\hline $0 / 0+\mathrm{BC}$ & $42.24^{\mathrm{bc}}$ & $30.03^{c}$ & $12.52^{\mathrm{b}}$ & $8.85^{\mathrm{b}}$ & 3.66 & $2.24^{\mathrm{b}}$ & $1.18^{\mathrm{bc}}$ & $0.42^{\mathrm{a}}$ & $1.59^{\mathrm{bc}}$ \\
\hline $0 / 0+\mathrm{DR}$ & $48.89^{\mathrm{b}}$ & $32.73^{\mathrm{bc}}$ & $13.25^{\mathrm{b}}$ & $8.95^{\mathrm{b}}$ & 3.49 & $2.61^{\mathrm{a}}$ & $1.2^{4 \mathrm{bc}}$ & $0.11^{\mathrm{b}}$ & $1.35^{\mathrm{b}-\mathrm{e}}$ \\
\hline $0 / 0+\mathrm{TR}$ & $49.54^{\mathrm{b}}$ & $43.43^{\mathrm{a}}$ & $19.36^{\mathrm{b}}$ & $8.40^{\mathrm{b}}$ & 3.55 & $2.11^{\mathrm{bc}}$ & $0.40^{\mathrm{e}}$ & $0.15^{\mathrm{b}}$ & $0.55^{\mathrm{e}}$ \\
\hline $41 / 46+\mathrm{BC}$ & $56.74^{\mathrm{b}}$ & $36.61^{\mathrm{b}}$ & $15.58^{\mathrm{b}}$ & $9.16^{\mathrm{ba}}$ & 3.68 & $2.61^{\mathrm{a}}$ & $1.38^{\mathrm{b}-\mathrm{d}}$ & $0.16^{\mathrm{b}}$ & $1.53^{\mathrm{bc}}$ \\
\hline $41 / 46+D R$ & $58.65^{\mathrm{b}}$ & $38.77^{\mathrm{a}}$ & $19.04^{\mathrm{a}}$ & $9.53^{\text {ba }}$ & 3.59 & $2.58^{\mathrm{b}}$ & $1.70^{\mathrm{a}}$ & $0.15^{\mathrm{b}}$ & $1.85^{\mathrm{ab}}$ \\
\hline 41/46+ TR & $49.42^{\mathrm{bc}}$ & $42.79^{\mathrm{a}}$ & $21.05^{\mathrm{a}}$ & $9.01^{\mathrm{b}}$ & 3.68 & $2.33^{\mathrm{b}}$ & $0.55^{\mathrm{e}}$ & $0.15^{\mathrm{b}}$ & $0.70^{\mathrm{e}}$ \\
\hline $61 / 69+\mathrm{BC}$ & $58.89^{\mathrm{a}}$ & $35.97^{\mathrm{bc}}$ & $16.09^{\text {ba }}$ & $9.43^{\text {ba }}$ & 3.63 & $2.71^{\mathrm{a}}$ & $1.78^{\mathrm{ab}}$ & $0.22^{\mathrm{b}}$ & $1.90^{\mathrm{ab}}$ \\
\hline $61 / 69+\mathrm{DR}$ & $59.70^{\mathrm{a}}$ & $40.28^{a}$ & $13.93^{\mathrm{b}}$ & $8.87^{\text {ba }}$ & 3.59 & $2.55^{\mathrm{b}}$ & $1.59^{\mathrm{ab}}$ & $0.15^{\mathrm{b}}$ & $1.72^{\mathrm{b}}$ \\
\hline $61 / 69+\mathrm{TR}$ & $49.54^{\mathrm{bc}}$ & $39.97^{\mathrm{a}}$ & $20.94^{\mathrm{a}}$ & $9.16^{\mathrm{ba}}$ & 3.43 & $2.25^{\mathrm{b}}$ & $0.59^{\mathrm{e}}$ & $0.19^{\mathrm{b}}$ & $0.78^{\mathrm{de}}$ \\
\hline $82 / 92+B C$ & $58.65^{\mathrm{a}}$ & $37.46^{\mathrm{b}}$ & $16.21^{\mathrm{ba}}$ & $9.44^{\mathrm{ba}}$ & 3.78 & $2.64^{\mathrm{a}}$ & $1.69^{\mathrm{ab}}$ & $0.13^{\mathrm{b}}$ & $1.82^{\mathrm{ab}}$ \\
\hline $82 / 92+\mathrm{DR}$ & $60.98^{\mathrm{a}}$ & $39.82^{\text {ba }}$ & $17.35^{\text {ba }}$ & $9.65^{\mathrm{a}}$ & 3.69 & $2.55^{\mathrm{b}}$ & $1.39^{\mathrm{bc}}$ & $0.12^{\mathrm{b}}$ & $1.51^{\mathrm{b}}$ \\
\hline $82 / 92+\mathrm{TR}$ & $51.02^{\mathrm{b}}$ & $43.44^{\mathrm{a}}$ & $18.45^{\mathrm{ba}}$ & $9.08^{\text {ba }}$ & 3.49 & $2.10^{\mathrm{b}}$ & $0.56^{\mathrm{e}}$ & $0.11^{\mathrm{b}}$ & $0.66^{\mathrm{e}}$ \\
\hline $102 / 115+\mathrm{BC}$ & $63.02^{\mathrm{a}}$ & $41.05^{\mathrm{ab}}$ & $18.71^{\mathrm{ba}}$ & $8.87^{\mathrm{b}}$ & 3.70 & $2.64^{\mathrm{a}}$ & $1.49^{\mathrm{ab}}$ & $0.21^{\mathrm{b}}$ & $1.70^{\mathrm{b}}$ \\
\hline $102 / 115$ + DR & $64.25^{\mathrm{a}}$ & $44.15^{\mathrm{a}}$ & $22.70^{\mathrm{a}}$ & $9.33^{\mathrm{a}}$ & 3.92 & $2.82^{\mathrm{a}}$ & $2.05^{\mathrm{a}}$ & $0.21^{\mathrm{b}}$ & $2.26^{\mathrm{a}}$ \\
\hline $102 / 115+$ TR & $51.05^{\mathrm{b}}$ & $43.29^{\mathrm{a}}$ & $20.32^{\mathrm{a}}$ & $8.75^{\mathrm{b}}$ & 3.66 & $2.43^{\mathrm{b}}$ & $0.78^{\mathrm{e}}$ & $0.18^{\mathrm{b}}$ & $0.97^{\mathrm{b}}$ \\
\hline Mean & 54.84 & 39.32 & 20.23 & 9.10 & 3.63 & 2.48 & 1.61 & 0.17 & 1.40 \\
\hline CV (\%) & 13.28 & 15.5 & 33.79 & 10.28 & 8.59 & 12.51 & 35.84 & 16.54 & 35.09 \\
\hline LSD 5\% & 7.47 & 6.11 & 7.18 & 0.54 & 0.39 & 0.27 & 0.49 & 0.13 & 0.55 \\
\hline F-test & $*$ & * & $*$ & $*$ & Ns & $*$ & $*$ & $*$ & $*$ \\
\hline
\end{tabular}

Means within column followed by the same letter (s) are not significantly different at $5 \%$ level of significance, LSD $(5 \%)=$ Least significant difference at $\mathrm{p}=$ 0.05 and $\mathrm{CV}(\%)=\mathrm{PH}=$ plant height, $\mathrm{CD}=$ canopy diameter, $\mathrm{FNPP}=$ fruit number per plant, $\mathrm{FL}=$ fruit length, $\mathrm{FW}=$ fruit weight, $\mathrm{MY}=$ marketable yield, $\mathrm{UNMY}=$ unmarketable yield $\mathrm{TYD}=$ total yield, Coefficient of variation in percent, $\mathrm{BC}=$ Broad casting, $\mathrm{TR}=$ Transplanting, $\mathrm{DR}=\mathrm{Drilling}$,

\subsection{Cost-Benefit Analysis}

Cost-benefit analysis undertaken for choosing the highest benefit-cost ratio as a result of using different levels of $\mathrm{N} / \mathrm{P}_{2} \mathrm{O}_{5}$ fertilizers using the three methods of hot pepper planting revealed that the maximum benefit-cost ratio. From the economic analysis of over location result, the highest net income (71572.25 Eth birr) and marginal rate of return (265.28\%) was obtained from treatment $102 / 115 \mathrm{~kg} \mathrm{~N} / \mathrm{P}_{2} \mathrm{O}_{5}$ ha $^{-1}$ with combined drilling sowing, while lowest net income (15201 Eth birr) was obtained from treatment 82/92 kg $\mathrm{N} / \mathrm{P}_{2} \mathrm{O}_{5} \mathrm{ha}^{-1}$ with transplanting method (Table 5).

Table 5. Partial budget and marginal rate of return analysis for effects of NP fertilizer rates and planting method at Boke and Daro labu districts during the 2016-2017 cropping season.

\begin{tabular}{|c|c|c|c|c|c|c|}
\hline $\begin{array}{l}\text { Fertilizer rate N/P (kg } \\
\text { ha }^{-1} \text { ) Planting method }\end{array}$ & $\begin{array}{l}\text { Marketable yield } \\
\text { (t/ha) }\end{array}$ & $\begin{array}{l}\text { Adjusted yield } \\
\text { (t/ha) }\end{array}$ & $\begin{array}{l}\text { Growth yield } \\
\text { benefit }\end{array}$ & $\begin{array}{l}\text { Total cost } \\
\text { (ETB) }\end{array}$ & $\begin{array}{l}\text { Net benefit } \\
\text { (ETB) }\end{array}$ & $\begin{array}{l}\text { Marginal } \\
\text { rate } \%\end{array}$ \\
\hline $0 / 0+\mathrm{BC}$ & 1.18 & 1.06 & 49284.00 & - & 49284 & - \\
\hline $0 / 0+\mathrm{DR}$ & 1.24 & 1.11 & 57852.00 & - & 57852 & - \\
\hline $0 / 0+\mathrm{TR}$ & 2.74 & 2.47 & 24436.80 & - & 24436.8 & - \\
\hline $41 / 46+\mathrm{BC}$ & 1.38 & 1.24 & 67752.00 & 2650.00 & 65344.5 & 2.67 \\
\hline $41 / 46+\mathrm{DR}$ & 1.70 & 1.53 & 73836.00 & 2900.00 & 71428.5 & 24.33 \\
\hline $41 / 46+\mathrm{TR}$ & 3.98 & 3.58 & 23792.40 & 3100.00 & 21384.9 & $\mathrm{D}$ \\
\hline $61 / 69+\mathrm{DR}$ & 1.59 & 1.43 & 63432.00 & 3975.00 & 59795.75 & $\mathrm{D}$ \\
\hline $61 / 69+\mathrm{TR}$ & 0.59 & 0.53 & 26064.00 & 2225.00 & 22427.75 & $\mathrm{D}$ \\
\hline $82 / 92+B C$ & 1.69 & 1.52 & 75636.00 & 7800.00 & 70821 & 84.16 \\
\hline $82 / 92+\mathrm{DR}$ & 1.39 & 1.25 & 54144.00 & 5050.00 & 49329 & $\mathrm{D}$ \\
\hline $82 / 92+\mathrm{TR}$ & 0.56 & 0.50 & 20016.00 & 5300.00 & 15201 & $\mathrm{D}$ \\
\hline $102 / 115+\mathrm{BC}$ & 1.49 & 1.34 & 77616.00 & 5512.50 & 71572.25 & 265.28 \\
\hline $102 / 115+\mathrm{DR}$ & 2.05 & 1.84 & 57888.00 & 5762.50 & 51844.25 & $\mathrm{D}$ \\
\hline
\end{tabular}

Where, NP cost $=$ Birr 11.6 and $12.6 \mathrm{~kg}^{-1}$ Urea and Dap respectively, fertilizers application cost, Birr $3.5 \mathrm{~kg}^{-1}$ of NP, Application cost of NP fertilizers 5 persons $100 \mathrm{~kg} \mathrm{ha}^{-1}$, each $70 \mathrm{ETB}$ day $^{-1}$, Price of dry pod yield $40 \mathrm{Birr} \mathrm{kg}^{-1}, \mathrm{D}=$ Dominated treatment

\section{Conclusion and Recommendation}

Nutrient requirement of hot pepper can be varied from location to location depending on different factors such as soil and other agro-ecologies. For sustainable production of hot pepper for a particular area, specific fertilizer recommendation is very crucial. For this reason, a field experiment was conducted during the 2016 to 2017 main cropping season. The results revealed significant $(p<0.5)$ difference in yield and yield related traits of the hot pepper. Highest marketable yield was obtained from treatment $102 / 115 \mathrm{~kg} \mathrm{~N} / \mathrm{P}_{2} \mathrm{O}_{5} \mathrm{ha}^{-1}$ with combined drilling sowing method (2.05 t/ha). According to the partial budget analysis, 
the highest economic benefits of $71428.5 \mathrm{ETH}$ birr/ha was obtained by using $102 / 115 \mathrm{~kg} \mathrm{~N} / \mathrm{P}_{2} \mathrm{O}_{5} \mathrm{ha}^{-1}$ with combined drilling sowing, as well as it has $49.82 \%$ yield advantage than control, which was superior in most of growth and yield parameters. Therefore, it can be concluded that the combined application of $102 / 115 \mathrm{~kg} \mathrm{~N} / \mathrm{P}_{2} \mathrm{O}_{5} \mathrm{ha}^{-1}$ with drilling sowing method can be recommended for the production of Hot pepper in the study area and other areas with similar agroecological conditions

\section{Acknowledgements}

Special thanks should go to Oromia Agricultural Research Institute to allocate all necessary budgets for this research. And my depth thanks goes to Mechara Agricultural research centre, and other Sister Research team, without their assistance and hospitability this paper may not be materialized.

\section{References}

[1] Rodriguez, Yaritza \& Depestre, Tomas \& Gomez, Olimpia. 2008. The efficiency of selection in pepper lines (Capsicum annuит), from four sub-populations, in characters of productive interest. Ciencia e Investigacion Agraria. 35. 29-40.

[2] Terry Berke and Subodh Joshi. 2005. Perspectives of Bell Pepper Breeding, Journal of New Seeds, 6: 2-3, 51-74, DOI: 10.1300/J153v06n02_04.

[3] Purseglove J. W., E. G. Brown, C. I., GREEN AND S. R. I. Robbins, 1981. Spices. 1 (1). LongmanInc. New York. 365p.

[4] Khan, M. S. \& Raj, S K. 2006. The first report of molecular detection of an Aster yellows phytoplasma ('Candidatus Phytoplasma asteris') isolates infecting chilli (Capsicum annuum) in India. Plant Pathology. 55. 822-822. 10.1111/j.1365-3059.2006.01482.

[5] Ahmed, J., U. S. Shivhare and G. S. V. Raghavan, 2000. Rheological characteristics and kinetics of colour degradations of green chilli puree. Journal of Food Engineering, 44: 239244.

[6] MARC (Melkasa Agricultural Research Center). 2004. Progress report, Addis Ababa, Ethiopia.

[7] CSA (Central Statistical Agency Ethiopia). 2018. Report on area and production of major crops. Agricultural sample survey. Addis Ababa Statistical Bulletin, 1 (584), 14-68.

[8] FAOSTAT (Food and Agriculture Organization). 2017. Food and Agriculture Organization of the United Nations, for a world without hunger. Rome, Italy. http://faostat.fao.org/site/567/.

[9] USAID (the United States on America Aid). 2013. From Sample Blended Fertilizers to Ample Yields. In: ethioagp.org/from-sample-blended-fertilizers-to-ample-yields.

[10] Mulat Demeke, Kelly, V, Jayne, T. S, Ali, S. Le, Vallee, J. C. and Chen, H. 1998. Agricultural market performance and determinants of fertiliser use in Ethiopia. pp. 1-69. Working paper 10. Grain market research project. Ministry of Economic Development and Cooperation, Addis Ababa, Ethiopia.
[11] Haverkort, A. J., Van Koesveld, M. J, Schepers, H. T. A. M, Wijnands, J. H. M, Wustman, R. and Zhang, X. X. 2012. Potato prospects for Ethiopia: on the road to value addition (No. 528). PPO AGV.

[12] Girma, T., Lidet, S., Damtrew, M., Daniel, B. 2001. Berber production in Ethiopia Grant, P. O. 1970. Restoration of productivity of depleted sands. Ardisia Agriculture. J. 67: 131137.

[13] Tibebu S and Bizuayehu T. 2014. Growth and productivity of hot pepper (Capsicum annuum 1.) as affected by variety, nitrogen and phosphorous at Jinka, Southern Ethiopia, Research Journal of Agriculture and Environmental Management. Vol. 3 (9), pp. 427-433.

[14] Kassa Melese. 2015. Seed multiplication and dry pod yield performance evaluation of improved pepper varieties in Northern Ethiopia, in case of central Tigray. International Journal of African and Asian Studies. 16: 2409-6938.

[15] Anonymous. 2012. hot pepper production manual for extension worker report.

[16] Kinde L, Asfaw Z. 2016. Effect of spacing and fertilizer dose on growth and yield of potato (Solanum tuberosum L) Gudane variety at West Hararghe, Eastern Ethiopia. International Journal of Horticulture and Ornamental Plants 2 (1): 011-018.

[17] ATA (Agricultural Transformation Agency). 2016. Transforming the use of fertilizer in Ethiopia: Launching the national fertilizer blending program, Addis Ababa.

[18] Daro labu woreda agricultural office, annual report, 2008, Annual report.

[19] Boke woreda agricultural and natural resource office, 2009, Annual report.

[20] EARO (Ethiopian Agricultural Research Organization). 2004. Directory of Released Crop Varieties \& Their Recommended Cultural Practices. Addis Ababa. 28-29p.

[21] CIMMYT. 1988. from agronomic data to farmer recommendations: An economics training manual. Retrieved from bitstream/handle/10883/830/ 13803 .

[22] USDA (United States Department of agriculture). 1987. Textural soil classification study guide. National Employee Development Staff. Soil Conservation Service, United States Department of Agriculture, Washington DC, USA.

[23] USDA (United State Department of Agriculture). 2015. Natural resources conservation service, examination and description of soil profiles. Online at: https://www.nrcs.usda.gov/wps/portal/nrcs/detail/soils/ref/?cid $=$ nrcs142p2-054253. [Accessed 13 August 2019.

[24] Tekalign Mamo, Tekalign Tadese and Aduayi E. A. 1991. Soil, plant, water, fertilizer, animal manure and compost analysis manual. Plant Science Division Working Document 13, ILCA, Addis Ababa, Ethiopia.

[25] Fageria, N. K, Baligar V. C, and Jones C. A. 2011. Growth and Mineral Nutrition of Field Crops. $3^{\text {rd }}$ Edition. Taylor \& Francis Group, NY, pp 530.

[26] Murphy, H. F. 1968. A Report on Fertility Status and Other Data on Some Soils of Ethiopia. Experimental Station Bulletin No. 44. College of Agriculture Dire Dawa, Ethiopia. $551 \mathrm{p}$. 
[27] Cotienie, A. 1980: Soil and plant testing as a base of fertilizer recommendation. FAO Soils BuH. 38 (2).

[28] Israel Zewide, Ali Mohammed and Solomon Tulu. 2012. Effect of Different Rates of Nitrogen and Phosphorus on Yield and Yield Components of Potato (Solanum tuberosum L.) at Masha District, Southwestern Ethiopia. International Journal of Soil Science, DOI: 10.3923/ijar.2016.95.104.

[29] Hintsa Meresa, Fantaye Belay and Atsbha Gebreslasie. 2017. Evaluation of NPS Fertilizer on Yield and Economic Performance of New Variety of Hot Pepper (Capsicum Annum L) in Tanqua Abergelle, Central Tigray, Ethiopia. Int. J. of Life Science, 7 (2).

[30] Kassa Melese, Wassu Mohammed and Gebre Hadgu. 2018. Response of Hot Pepper (Capsicum annuиm L.) as Affected by NP Fertilizer and Farmyard Manure Combined Application in Raya Azebo District, Northern Ethiopia. Int. J. of. Life Sciences, Volume 6 (4): 831-848.

[31] El-Tohamy WA, Ghoname AA and Abou-Hussein SD. 2006. Improvement of pepper growth and productivity in sandy soil by different fertilization treatments under protected cultivation. Journal of Applied Science Research, 2: 8-12.

[32] Ayodele O. J, Alabi E. O, Aluko M. 2015. Nitrogen Fertilizer Effects on Growth, Yield and Chemical Composition of Hot Pepper (Rodo). International Journal of Agriculture and Crop Sciences.

[33] Addisalem Mebratu. 2011. Response of pepper (Capsicum annuum L.) to the application of nitrogen and potassium fertilizers at Agarfa, South Eastern highland of Ethiopia. MSc Thesis, Haramaya University, Haramaya, Ethiopia.

[34] Russo, V. M. 2003. Planting date and plant density affect fruit seed of Jalapeno peppers. Journal of Horticulture Science, 38: $520-523$.

[35] Adugna Z. (2008). Effects of Seed Priming, Planting Method and Fertilizers on Yield and Yield Components of Fresh Hot Pepper (Capsicum annuum L.) in North-west Ethiopia. MSc Thesis Presented to the School of Graduate Studies of Haramaya University. 74pp.

[36] Leghari GM and Oad FC. 2005. The effect of nitrogen fertilizer regimes on the growth and yield of pepper. Indus Journal of Plant Science, 4 (3): 386-390.

[37] Adisalem Mebratu, Nugusie Dechassa, Kebede and Weldetsadik. 2014. Effect of Inorganic Fertilizers on Yield and Physical Quality Parameters of Hot Pepper (Capsicum annuum L.) in South-Eastern Ethiopia. Journal of Plant and Pest Science. 1 (3): 138-145.

[38] Nimona F and Girma A. 2018. Effects of blended fertilizer types and rates on fruit yield and nutrient use efficiencies of hot pepper (Capsicum annuum L.) at Asossa, Western Ethiopia. African Journal of Agricultural Research. Vol. 14 (33), pp. 1737-1748.

[39] Hedge DM. 1997. Nutrition requirement of solanaceous Vegetable crops, All India Coordinated Safflowers Improvement Project. Solapur, Maharashtra, India. In: Food and Fertilizer Technology centre. Taipie, 10616 Taiwan, R. O. C. www.agent.org/.

[40] Baghour, M., E. Sanchez, J. M. Ruiz, and L. Romero. 2001. Metabolism and efficiency of phosphorus utilization during senescence in pepper plants: Response to Nitrogenous and Potassium fertilization. Journal of Plant Nutrition, 24 (11), 1731-1743. 